\title{
Best proximity points of generalized almost $\psi$-Geraghty contractive non-self-mappings
}

\author{
Hassen Aydi ${ }^{1}$, Erdal Karapınar ${ }^{2,3}$, Inci M Erhan ${ }^{2 *}$ and Peyman Salimi ${ }^{4}$
}

${ }^{*}$ Correspondence:

ierhan@atilim.edu.tr;

incierhan@gmail.com

2 Department of Mathematics,

Atilim University, İncek, Ankara

06836, Turkey

Full list of author information is

available at the end of the article

\begin{abstract}
In this paper, we introduce the new notion of almost $\psi$-Geraghty contractive mappings and investigate the existence of a best proximity point for such mappings in complete metric spaces via the weak $P$-property. We provide an example to validate our best proximity point theorem. The obtained results extend, generalize, and complement some known fixed and best proximity point results from the literature.

MSC: $47 \mathrm{H} 10 ; 54 \mathrm{H} 25 ; 46 \mathrm{~J} 10 ; 46 \mathrm{~J} 15$
\end{abstract}

Keywords: fixed point; metric space; best proximity point; generalized almost $\psi$-Geraghty contractions

\section{Introduction and preliminaries}

Non-self-mappings are among the intriguing research directions in fixed point theory. This is evident from the increase of the number of publications related with such maps. A great deal of articles on the subject investigate the non-self-contraction mappings on metric spaces. Let $(X, d)$ be a metric space and $A$ and $B$ be nonempty subsets of $X$. A mapping $T: A \rightarrow B$ is said to be a $k$-contraction if there exists $k \in[0,1)$ such that $d(T x, T y) \leq k d(x, y)$ for any $x, y \in A$. It is clear that a $k$-contraction coincides with the celebrated Banach fixed point theorem (Banach contraction principle) [1] if one takes $A=B$ where the induced metric space $\left(A,\left.d\right|_{A}\right)$ is complete.

In nonlinear analysis, the theory of fixed points is an essential instrument to solve the equation $T x=x$ for a self-mapping $T$ defined on a subset of an abstract space such as a metric space, a normed linear space or a topological vector space. Following the Banach contraction principle, most of the fixed point results have been proved for a self-mapping defined on an abstract space. It is quite natural to investigate the existence and uniqueness of a non-self-mapping $T: A \rightarrow B$ which does not possess a fixed point. If a non-selfmapping $T: A \rightarrow B$ has no fixed point, then the answer of the following question makes sense: Is there a point $x \in X$ such that the distance between $x$ and $T x$ is closest in some sense? Roughly speaking, best proximity theory investigates the existence and uniqueness of such a closest point $x$. We refer the reader to [2-9] and [10-32] for further discussion of best proximity.

@2014 Aydi et al.; licensee Springer. This is an Open Access article distributed under the terms of the Creative Commons Attribution License (http://creativecommons.org/licenses/by/2.0), which permits unrestricted use, distribution, and reproduction in any medium, provided the original work is properly cited. 
Definition 1.1 Let $(X, d)$ be a metric space and $A, B \subset X$. We say that $x^{*} \in A$ is a best proximity point of the non-self-mapping $T: A \rightarrow B$ if the following equality holds:

$$
d\left(x^{*}, T x^{*}\right)=d(A, B)
$$

where $d(A, B)=\inf \{d(x, y): x \in A, y \in B\}$.

It is clear that the notion of a fixed point coincided with the notion of a best proximity point when the underlying mapping is a self-mapping.

Let $(X, d)$ be a metric space. Suppose that $A$ and $B$ are nonempty subsets of a metric space $(X, d)$. We define the following sets:

$$
\begin{aligned}
& A_{0}=\{x \in A: d(x, y)=d(A, B) \text { for some } y \in B\}, \\
& B_{0}=\{y \in B: d(x, y)=d(A, B) \text { for some } x \in A\} .
\end{aligned}
$$

In [17], the authors presented sufficient conditions for the sets $A_{0}$ and $B_{0}$ to be nonempty. In 1973 Geraghty [33] introduced the class $S$ of functions $\beta:[0, \infty) \rightarrow[0,1)$ satisfying the following condition:

$$
\beta\left(t_{n}\right) \rightarrow 1 \text { implies } t_{n} \rightarrow 0 \text {. }
$$

The author defined contraction mappings via functions from this class and proved the following result.

Theorem 1.1 (Geraghty [33]) Let $(X, d)$ be a complete metric space and $T: X \rightarrow X$ be an operator. If $T$ satisfies the following inequality:

$$
d(T x, T y) \leq \beta(d(x, y)) d(x, y) \quad \text { for any } x, y \in X
$$

where $\beta \in S$, then $T$ has a unique fixed point.

Recently, Caballero et al. [6] introduced the following contraction.

Definition 1.2 ([6]) Let $A, B$ be two nonempty subsets of a metric space $(X, d)$. A mapping $T: A \rightarrow B$ is said to be a Geraghty-contraction if there exists $\beta \in S$ such that

$$
d(T x, T y) \leq \beta(d(x, y)) d(x, y) \quad \text { for any } x, y \in A
$$

Based on Definition 1.2, the authors [6] obtained the following result.

Theorem 1.2 (See [6]) Let $(A, B)$ be a pair of nonempty closet subsets of a complete metric space $(X, d)$ such that $A_{0}$ is nonempty. Let $T: A \rightarrow B$ be a continuous, Geraghty-contraction satisfying $T\left(A_{0}\right) \subseteq B_{0}$. Suppose that the pair $(A, B)$ has the P-property, then there exists a unique $x^{*}$ in $A$ such that $d\left(x^{*}, T x^{*}\right)=d(A, B)$.

The $P$-property mentioned in the theorem above has been introduced in [29]. 
Definition 1.3 Let $(A, B)$ be a pair of nonempty subsets of a metric space $(X, d)$ with $A_{0} \neq \emptyset$. Then the pair $(A, B)$ is said to have the $P$-property if and only if for any $x_{1}, x_{2} \in A_{0}$ and $y_{1}, y_{2} \in B_{0}$,

$$
d\left(x_{1}, y_{1}\right)=d(A, B) \quad \text { and } \quad d\left(x_{2}, y_{2}\right)=d(A, B) \quad \Rightarrow \quad d\left(x_{1}, x_{2}\right)=d\left(y_{1}, y_{2}\right) .
$$

It is easily seen that for any nonempty subset $A$ of $(X, d)$, the pair $(A, A)$ has the $P$-property. In [29], the author proved that any pair $(A, B)$ of nonempty closed convex subsets of a real Hilbert space $H$ satisfies the $P$-property.

Recently, Zhang et al. [34] defined the following notion, which is weaker than the $P$-property.

Definition 1.4 Let $(A, B)$ be a pair of nonempty subsets of a metric space $(X, d)$ with $A_{0} \neq \emptyset$. Then the pair $(A, B)$ is said to have the weak $P$-property if and only if for any $x_{1}, x_{2} \in A_{0}$ and $y_{1}, y_{2} \in B_{0}$,

$$
d\left(x_{1}, y_{1}\right)=d(A, B) \quad \text { and } \quad d\left(x_{2}, y_{2}\right)=d(A, B) \quad \Rightarrow \quad d\left(x_{1}, x_{2}\right) \leq d\left(y_{1}, y_{2}\right) .
$$

Let $\Psi$ denote the class of functions $\psi:[0, \infty) \rightarrow[0, \infty)$ satisfying the following conditions:

(a) $\psi$ is nondecreasing;

(b) $\psi$ is subadditive, that is, $\psi(s+t) \leq \psi(s)+\psi(t)$;

(c) $\psi$ is continuous;

(d) $\psi(t)=0 \Leftrightarrow t=0$.

The notion of $\psi$-Geraghty contraction has been introduced very recently in [11], as an extension of Definition 1.2.

Definition 1.5 Let $A, B$ be two nonempty subsets of a metric space $(X, d)$. A mapping $T: A \rightarrow B$ is said to be a $\psi$-Geraghty contraction if there exist $\beta \in S$ and $\psi \in \Psi$ such that

$$
\psi(d(T x, T y)) \leq \beta(\psi(d(x, y))) \psi(d(x, y)) \quad \text { for any } x, y \in A .
$$

Remark 1.1 Notice that since $\beta:[0, \infty) \rightarrow[0,1)$, we have

$$
\begin{aligned}
& \psi(d(T x, T y)) \leq \beta(\psi(d(x, y))) \psi(d(x, y))<\psi(d(x, y)) \\
& \quad \text { for any } x, y \in A \text { with } x \neq y .
\end{aligned}
$$

In [11], the author also proved the following best proximity point theorem.

Theorem 1.3 (See [11]) Let $(A, B)$ be a pair of nonempty closed subsets of a complete metric space $(X, d)$ such that $A_{0}$ is nonempty. Let $T: A \rightarrow B$ be a $\psi$-Geraghty contraction satisfying $T\left(A_{0}\right) \subseteq B_{0}$. Suppose that the pair $(A, B)$ has the P-property. Then there exists a unique $x^{*}$ in $A$ such that $d\left(x^{*}, T x^{*}\right)=d(A, B)$.

\section{Main results}

Our main results are based on the following definition which is a generalization of Definition 1.5 . 
Definition 2.1 Let $A, B$ be two nonempty subsets of a metric space $(X, d)$. A mapping $T: A \rightarrow B$ is said to be a generalized almost $\psi$-Geraghty contraction if there exist $\beta \in S$ and $\psi \in \Psi$ such that

$$
\psi(d(T x, T y)) \leq \beta(\psi(M(x, y))) \psi(M(x, y)-d(A, B))+L \psi(N(x, y)-d(A, B))
$$

for all $x, y \in A$ where $L \geq 0$,

$$
\begin{aligned}
& M(x, y)=\max \{d(x, y), d(x, T x), d(y, T y)\}, \\
& N(x, y)=\min \{d(x, T x), d(y, T y), d(x, T y), d(y, T x)\} .
\end{aligned}
$$

Now, we state and prove our main theorem about existence and uniqueness of a best proximity point for a non-self-mapping satisfying a generalized almost $\psi$-Geraghty contraction.

Theorem 2.1 Let $(A, B)$ be a pair of nonempty closed subsets of a complete metric space $(X, d)$ such that $A_{0}$ is nonempty. Let $T: A \rightarrow B$ be a generalized almost $\psi$-Geraghty contraction satisfying $T\left(A_{0}\right) \subseteq B_{0}$. Assume that the pair $(A, B)$ has the weak P-property. Then $T$ has a unique best proximity point in $A$.

Proof Since the subset $A_{0}$ is not empty, we can take $x_{0}$ in $A_{0}$. Taking into account that $T x_{0} \in T\left(A_{0}\right) \subseteq B_{0}$, we can find $x_{1} \in A_{0}$ such that $d\left(x_{1}, T x_{0}\right)=d(A, B)$. Further, since $T x_{1} \in T\left(A_{0}\right) \subseteq B_{0}$, it follows that there is an element $x_{2}$ in $A_{0}$ such that $d\left(x_{2}, T x_{1}\right)=d(A, B)$. Recursively, we obtain a sequence $\left\{x_{n}\right\}$ in $A_{0}$ satisfying

$$
d\left(x_{n+1}, T x_{n}\right)=d(A, B) \quad \text { for any } n \in \mathbb{N} .
$$

Since the pair $(A, B)$ has the weak $P$-property, we deduce

$$
d\left(x_{n}, x_{n+1}\right) \leq d\left(T x_{n-1}, T x_{n}\right) \quad \text { for any } n \in \mathbb{N} \text {. }
$$

Due to the triangle inequality together with the equality (11) we have

$$
d\left(x_{n-1}, T x_{n-1}\right) \leq d\left(x_{n-1}, x_{n}\right)+d\left(x_{n}, T x_{n-1}\right)=d\left(x_{n-1}, x_{n}\right)+d(A, B) .
$$

Analogously, combining the equalities (11) and (12) with the triangle inequality we obtain

$$
d\left(x_{n}, T x_{n}\right) \leq d\left(x_{n}, x_{n+1}\right)+d\left(x_{n+1}, T x_{n}\right)=d\left(x_{n}, x_{n+1}\right)+d(A, B) .
$$

Consequently, we have

$$
\begin{aligned}
M\left(x_{n-1}, x_{n}\right) & =\max \left\{d\left(x_{n-1}, x_{n}\right), d\left(x_{n-1}, T x_{n-1}\right), d\left(x_{n}, T x_{n}\right)\right\} \\
& \leq \max \left\{d\left(x_{n-1}, x_{n}\right), d\left(x_{n}, x_{n+1}\right)\right\}+d(A, B) .
\end{aligned}
$$


Also note that

$$
\begin{aligned}
& N\left(x_{n-1}, x_{n}\right)-d(A, B) \\
& \quad=\min \left\{d\left(x_{n-1}, T x_{n-1}\right), d\left(x_{n}, T x_{n}\right), d\left(x_{n-1}, T x_{n}\right), d\left(x_{n}, T x_{n-1}\right)\right\}-d(A, B) \\
& \quad \leq \min \left\{d\left(x_{n-1}, T x_{n-1}\right), d\left(x_{n}, T x_{n}\right), d\left(x_{n-1}, T x_{n}\right), d(A, B)\right\}-d(A, B) \\
& \quad=d(A, B)-d(A, B)=0 .
\end{aligned}
$$

If there exists $n_{0} \in \mathbb{N}$ such that $d\left(x_{n_{0}}, x_{n_{0}+1}\right)=0$, then the proof is completed. Indeed,

$$
0=d\left(x_{n_{0}}, x_{n_{0}+1}\right)=d\left(T x_{n_{0}-1}, T x_{n_{0}}\right),
$$

and consequently, $T x_{n_{0}-1}=T x_{n_{0}}$. Therefore, we conclude that

$$
d(A, B)=d\left(x_{n_{0}}, T x_{n_{0}-1}\right)=d\left(x_{n_{0}}, T x_{n_{0}}\right) .
$$

For the rest of the proof, we suppose that $d\left(x_{n}, x_{n+1}\right)>0$ for all $n \in \mathbb{N}$. In view of the fact that $T$ is a generalized almost $\psi$-Geraghty contraction, we have

$$
\begin{aligned}
\psi\left(d\left(x_{n}, x_{n+1}\right)\right) \leq & \psi\left(d\left(T x_{n-1}, T x_{n}\right)\right) \\
\leq & \beta\left(\psi\left(M\left(x_{n-1}, x_{n}\right)\right)\right) \psi\left(M\left(x_{n-1}, x_{n}\right)-d(A, B)\right) \\
& \quad+L \psi\left(N\left(x_{n-1}, x_{n}\right)-d(A, B)\right) \\
= & \beta\left(\psi\left(M\left(x_{n-1}, x_{n}\right)\right)\right) \psi\left(M\left(x_{n-1}, x_{n}\right)-d(A, B)\right)+L \psi(0) \\
= & \beta\left(\psi\left(M\left(x_{n-1}, x_{n}\right)\right)\right) \psi\left(M\left(x_{n-1}, x_{n}\right)-d(A, B)\right) \\
< & \psi\left(M\left(x_{n-1}, x_{n}\right)-d(A, B)\right) .
\end{aligned}
$$

Taking into account the inequalities (14) and (18), we deduce that

$$
\psi\left(d\left(x_{n}, x_{n+1}\right)\right)<\psi\left(M\left(x_{n-1}, x_{n}\right)-d(A, B)\right) \leq \psi\left(\max \left\{d\left(x_{n-1}, x_{n}\right), d\left(x_{n}, x_{n+1}\right)\right\}\right) .
$$

If for some $n, \max \left\{d\left(x_{n-1}, x_{n}\right), d\left(x_{n}, x_{n+1}\right)\right\}=d\left(x_{n}, x_{n+1}\right)$, then we get

$$
\psi\left(d\left(x_{n}, x_{n+1}\right)\right)<\psi\left(d\left(x_{n}, x_{n+1}\right)\right)
$$

which is a contradiction. Therefore, we must have

$$
M\left(x_{n-1}, x_{n}\right) \leq \max \left\{d\left(x_{n-1}, x_{n}\right), d\left(x_{n}, x_{n+1}\right)\right\}+d(A, B)=d\left(x_{n-1}, x_{n}\right)+d(A, B)
$$

for all $n \in \mathbb{N}$. Regarding the inequality (18), we see that

$$
\begin{aligned}
\psi\left(d\left(x_{n}, x_{n+1}\right)\right) & =\psi\left(d\left(T x_{n-1}, T x_{n}\right)\right) \\
& \leq \beta\left(\psi\left(M\left(x_{n-1}, x_{n}\right)\right)\right) \psi\left(d\left(x_{n-1}, x_{n}\right)\right) \\
& <\psi\left(d\left(x_{n-1}, x_{n}\right)\right)
\end{aligned}
$$


holds for all $n \in \mathbb{N}$. Since $\psi$ is nondecreasing, then $d\left(x_{n}, x_{n+1}\right)<d\left(x_{n-1}, x_{n}\right)$ for all $n$. Consequently, the sequence $\left\{d\left(x_{n}, x_{n+1}\right)\right\}$ is decreasing and is bounded below and hence $\lim _{n \rightarrow \infty} d\left(x_{n}, x_{n+1}\right)=s \geq 0$ exists. Assume that $s>0$. Rewrite (20) as

$$
\frac{\psi\left(d\left(x_{n+1}, x_{n+2}\right)\right)}{\psi\left(d\left(x_{n}, x_{n+1}\right)\right)} \leq \beta\left(\psi\left(M\left(x_{n}, x_{n+1}\right)\right)\right) \leq 1
$$

for each $n \geq 1$. Taking the limit of both sides as $n \rightarrow \infty$, we find

$$
\lim _{n \rightarrow \infty} \beta\left(\psi\left(M\left(x_{n}, x_{n+1}\right)\right)\right)=1 .
$$

On the other hand, since $\beta \in S$, we conclude $\lim _{n \rightarrow \infty} \psi\left(M\left(x_{n}, x_{n+1}\right)\right)=0$, that is,

$$
s=\lim _{n \rightarrow \infty} d\left(x_{n}, x_{n+1}\right)=0 .
$$

Since $d\left(x_{n}, T x_{n-1}\right)=d(A, B)$ holds for all $n \in \mathbb{N}$ and $(A, B)$ satisfies the weak $P$-property, then for all $m, n \in \mathbb{N}$, we can write

$$
d\left(x_{m}, x_{n}\right) \leq d\left(T x_{m-1}, T x_{n-1}\right) .
$$

From (13), we deduce

$$
\begin{aligned}
M\left(x_{m}, x_{n}\right) & =\max \left\{d\left(x_{m}, x_{n}\right), d\left(x_{m}, T x_{m}\right), d\left(x_{n}, T x_{n}\right)\right\} \\
& \leq \max \left\{d\left(x_{m}, x_{n}\right), d\left(x_{m}, x_{m+1}\right), d\left(x_{n}, x_{n+1}\right)\right\}+d(A, B) .
\end{aligned}
$$

By using $\lim _{n \rightarrow \infty} d\left(x_{n}, x_{n+1}\right)=0$, we get

$$
\lim _{m, n \rightarrow \infty}\left(M\left(x_{m}, x_{n}\right)-d(A, B)\right) \leq \lim _{m, n \rightarrow \infty} d\left(x_{m}, x_{n}\right) .
$$

On the other hand,

$$
\begin{aligned}
0 & \leq N\left(x_{m}, x_{n}\right)-d(A, B) \\
& =\min \left\{d\left(x_{m}, T x_{m}\right), d\left(x_{n}, T x_{n}\right), d\left(x_{m}, T x_{n}\right), d\left(x_{n}, T x_{m}\right)\right\}-d(A, B) \\
& \leq \min \left\{d\left(x_{m}, x_{m+1}\right)+d(A, B), d\left(x_{n}, T x_{n}\right), d\left(x_{m}, T x_{n}\right), d\left(x_{n}, T x_{m}\right)\right\}-d(A, B) .
\end{aligned}
$$

Due to the fact that $\lim _{n \rightarrow \infty} d\left(x_{n}, x_{n+1}\right)=0$, we obtain

$$
\lim _{m, n \rightarrow \infty}\left[N\left(x_{m}, x_{n}\right)-d(A, B)\right]=0 .
$$

We shall show next that $\left\{x_{n}\right\}$ is a Cauchy sequence. Assume on the contrary that

$$
\varepsilon=\limsup _{m, n \rightarrow \infty} d\left(x_{n}, x_{m}\right)>0 .
$$

Employing the triangular inequality and (22), we get

$$
\begin{aligned}
d\left(x_{n}, x_{m}\right) & \leq d\left(x_{n}, x_{n+1}\right)+d\left(x_{n+1}, x_{m+1}\right)+d\left(x_{m+1}, x_{m}\right) \\
& \leq d\left(x_{n}, x_{n+1}\right)+d\left(T x_{n}, T x_{m}\right)+d\left(x_{m+1}, x_{m}\right) .
\end{aligned}
$$


Combining (10) and (27), and regarding the properties of $\psi$, we obtain

$$
\begin{aligned}
\psi\left(d\left(x_{n}, x_{m}\right)\right) \leq & \psi\left(d\left(x_{n}, x_{n+1}\right)+d\left(T x_{n}, T x_{m}\right)+d\left(x_{m+1}, x_{m}\right)\right) \\
\leq & \psi\left(d\left(x_{n}, x_{n+1}\right)\right)+\psi\left(d\left(T x_{n}, T x_{m}\right)\right)+\psi\left(d\left(x_{m+1}, x_{m}\right)\right) \\
\leq & \psi\left(d\left(x_{n}, x_{n+1}\right)\right)+\beta\left(\psi\left(M\left(x_{n}, x_{m}\right)\right)\right) \psi\left(M\left(x_{n}, x_{m}\right)-d(A, B)\right) \\
& +L \psi\left(N\left(x_{n}, x_{m}\right)-d(A, B)\right)+\psi\left(d\left(x_{m+1}, x_{m}\right)\right) .
\end{aligned}
$$

From (23), (25), (28), and by using $\lim _{n \rightarrow \infty} d\left(x_{n}, x_{n+1}\right)=0$, we have

$$
\begin{aligned}
\lim _{m, n \rightarrow \infty} \psi\left(d\left(x_{n}, x_{m}\right)\right) & \leq \lim _{m, n \rightarrow \infty} \beta\left(\psi\left(M\left(x_{n}, x_{m}\right)\right)\right) \lim _{m, n \rightarrow \infty} \psi\left(M\left(x_{m}, x_{n}\right)-d(A, B)\right) \\
& \leq \lim _{m, n \rightarrow \infty} \beta\left(\psi\left(M\left(x_{n}, x_{m}\right)\right)\right) \lim _{m, n \rightarrow \infty} \psi\left(d\left(x_{m}, x_{n}\right)\right) .
\end{aligned}
$$

So by (26), we get

$$
1 \leq \lim _{m, n \rightarrow \infty} \beta\left(\psi\left(M\left(x_{n}, x_{m}\right)\right)\right)
$$

that is, $\lim _{m, n \rightarrow \infty} \beta\left(\psi\left(M\left(x_{n}, x_{m}\right)\right)\right)=1$. Therefore, $\lim _{m, n \rightarrow \infty} M\left(x_{n}, x_{m}\right)=0$. This implies that $\lim _{m, n \rightarrow \infty} d\left(x_{n}, x_{m}\right)=0$, which is a contradiction. Therefore, $\left\{x_{n}\right\}$ is a Cauchy sequence.

Since $\left\{x_{n}\right\} \subset A$ and $A$ is a closed subset of the complete metric space $(X, d)$, we can find $x^{*} \in A$ such that $x_{n} \rightarrow x^{*}$ as $n \rightarrow \infty$. We shall show that $d\left(x^{*}, T x^{*}\right)=d(A, B)$. If $x^{*}=T x^{*}$, then $A \cap B \neq \emptyset$, and $d\left(x^{*}, T x^{*}\right)=d(A, B)=0$, i.e., $x^{*}$ is a best proximity point of $T$. Hence, we assume that $d\left(x^{*}, T x^{*}\right)>0$. Suppose on the contrary that $x^{*}$ is not a best proximity point of $T$, that is, $d\left(x^{*}, T x^{*}\right)>d(A, B)$. First note that

$$
\begin{aligned}
d\left(x^{*}, T x^{*}\right) & \leq d\left(x^{*}, T x_{n}\right)+d\left(T x_{n}, T x^{*}\right) \\
& \leq d\left(x^{*}, x_{n+1}\right)+d\left(x_{n+1}, T x_{n}\right)+d\left(T x_{n}, T x^{*}\right) \\
& \leq d\left(x^{*}, x_{n+1}\right)+d(A, B)+d\left(T x_{n}, T x^{*}\right) .
\end{aligned}
$$

Taking the limit as $n \rightarrow \infty$ in the above inequality, we obtain

$$
d\left(x^{*}, T x^{*}\right)-d(A, B) \leq \lim _{n \rightarrow \infty} d\left(T x_{n}, T x^{*}\right)
$$

Since $\psi$ is nondecreasing and continuous, then

$$
\psi\left(d\left(x^{*}, T x^{*}\right)-d(A, B)\right) \leq \psi\left(\lim _{n \rightarrow \infty} d\left(T x_{n}, T x^{*}\right)\right)=\lim _{n \rightarrow \infty} \psi\left(d\left(T x_{n}, T x^{*}\right)\right)
$$

Also, letting $n \rightarrow \infty$ in (13) results in

$$
\lim _{n \rightarrow \infty} d\left(x_{n}, T x_{n}\right) \leq d(A, B)
$$

that is, $\lim _{n \rightarrow \infty} d\left(x_{n}, T x_{n}\right)=d(A, B)$. Then we get

$$
\lim _{n \rightarrow \infty} M\left(x_{n}, x^{*}\right)=\max \left\{\lim _{n \rightarrow \infty} d\left(x^{*}, x_{n}\right), \lim _{n \rightarrow \infty} d\left(x_{n}, T x_{n}\right), d\left(x^{*}, T x^{*}\right)\right\}=d\left(x^{*}, T x^{*}\right),
$$


and therefore

$$
\lim _{n \rightarrow \infty} \psi\left(M\left(x_{n}, x^{*}\right)-d(A, B)\right)=\psi\left(d\left(x^{*}, T x^{*}\right)-d(A, B)\right) .
$$

Further,

$$
\begin{aligned}
& \lim _{n \rightarrow \infty} N\left(x_{n}, x^{*}\right)-d(A, B) \\
& \quad=\min \left\{\lim _{n \rightarrow \infty} d\left(x_{n}, T x_{n}\right), d\left(x^{*}, T x^{*}\right), \lim _{n \rightarrow \infty} d\left(x_{n}, T x^{*}\right), \lim _{n \rightarrow \infty} d\left(x^{*}, T x_{n}\right)\right\}-d(A, B),
\end{aligned}
$$

which implies

$$
\lim _{n \rightarrow \infty} N\left(x_{n}, x^{*}\right)-d(A, B)=0
$$

Therefore, combining (10), (29), (30), and (31) we deduce

$$
\begin{aligned}
\psi\left(d\left(x^{*}, T x^{*}\right)-d(A, B)\right) \leq & \lim _{n \rightarrow \infty} \psi\left(d\left(T x_{n}, T x^{*}\right)\right) \\
\leq & \lim _{n \rightarrow \infty} \beta\left(\psi\left(M\left(x_{n}, x^{*}\right)\right)\right) \lim _{n \rightarrow \infty} \psi\left(M\left(x_{n}, x^{*}\right)-d(A, B)\right) \\
& +L \lim _{n \rightarrow \infty} \psi\left(N\left(x_{n}, x^{*}\right)-d(A, B)\right) \\
= & \lim _{n \rightarrow \infty} \beta\left(\psi\left(M\left(x_{n}, x^{*}\right)\right)\right) \psi\left(d\left(x^{*}, T x^{*}\right)-d(A, B)\right) .
\end{aligned}
$$

Now, since $\psi\left(d\left(x^{*}, T x^{*}\right)-d(A, B)\right)>0$, and making use of (32), we get

$$
1 \leq \lim _{n \rightarrow \infty} \beta\left(\psi\left(M\left(x_{n}, x^{*}\right)\right)\right),
$$

that is,

$$
\lim _{n \rightarrow \infty} \beta\left(\psi\left(M\left(x_{n}, x^{*}\right)\right)\right)=1,
$$

which implies

$$
\lim _{n \rightarrow \infty} M\left(x_{n}, x^{*}\right)=d\left(x^{*}, T x^{*}\right)=0
$$

and so $d\left(x^{*}, T x^{*}\right)=0>d(A, B)$, which is a contradiction. Therefore, $d\left(x^{*}, T x^{*}\right) \leq d(A, B)$, that is, $d\left(x^{*}, T x^{*}\right)=d(A, B)$. In other words, $x^{*}$ is a best proximity point of $T$. This completes the proof of the existence of a best proximity point.

We shall show next the uniqueness of the best proximity point of $T$. Suppose that $x^{*}$ and $y^{*}$ are two best proximity points of $T$, such that $x^{*} \neq y^{*}$. This implies that

$$
d\left(x^{*}, T x^{*}\right)=d(A, B)=d\left(y^{*}, T y^{*}\right),
$$

where $d\left(x^{*}, y^{*}\right)>0$. Due to the weak $P$-property of the pair $(A, B)$, we have

$$
d\left(x^{*}, y^{*}\right) \leq d\left(T x^{*}, T y^{*}\right) .
$$


Observe that in this case

$$
\begin{aligned}
M\left(x^{*}, y^{*}\right) & =\max \left\{d\left(x^{*}, y^{*}\right), d\left(x^{*}, T x^{*}\right), d\left(y^{*}, T y^{*}\right)\right\} \\
& =\max \left\{d\left(x^{*}, y^{*}\right), d(A, B), d(A, B)\right\} .
\end{aligned}
$$

Also, note that

$$
\begin{aligned}
N\left(x^{*}, y^{*}\right)-d(A, B) & =\min \left\{d\left(x^{*}, T x^{*}\right), d\left(y^{*}, T y^{*}\right), d\left(x^{*}, T y^{*}\right), d\left(y^{*}, T x^{*}\right)\right\}-d(A, B) \\
& =\min \left\{d(A, B), d(A, B), d\left(x^{*}, T y^{*}\right), d\left(y^{*}, T x^{*}\right)\right\}-d(A, B) \\
& =d(A, B)-d(A, B)=0 .
\end{aligned}
$$

Using the fact that $T$ is a generalized almost $\psi$-Geraghty contraction, we derive

$$
\begin{aligned}
\psi\left(d\left(x^{*}, y^{*}\right)\right) & \leq \psi\left(d\left(T x^{*}, T y^{*}\right)\right) \\
& \leq \beta\left(\psi\left(M\left(x^{*}, y^{*}\right)\right)\right) \psi\left(M\left(x^{*}, y^{*}\right)-d(A, B)\right)+L \psi\left(N\left(x^{*}, y^{*}\right)-d(A, B)\right) \\
& =\beta\left(\psi\left(M\left(x^{*}, y^{*}\right)\right)\right) \psi\left(M\left(x^{*}, y^{*}\right)-d(A, B)\right) \\
& <\psi\left(M\left(x^{*}, y^{*}\right)-d(A, B)\right) .
\end{aligned}
$$

If $M\left(x^{*}, y^{*}\right)=d(A, B)$, due to the fact that $d\left(x^{*}, y^{*}\right)>0$, the inequality above becomes

$$
0<\psi\left(d\left(x^{*}, y^{*}\right)\right)<\psi(0)
$$

which implies $d\left(x^{*}, y^{*}\right)=0$ and contradicts the assumption $d\left(x^{*}, y^{*}\right)>0$. Else, if $M\left(x^{*}, y^{*}\right)=$ $d\left(x^{*}, y^{*}\right)$, we deduce

$$
0<\psi\left(d\left(x^{*}, y^{*}\right)\right)<\psi\left(d\left(x^{*}, y^{*}\right)-d(A, B)\right)
$$

which is not possible, since $\psi$ is nondecreasing. Therefore, we must have $d\left(x^{*}, y^{*}\right)=0$. This completes the proof.

To illustrate our result given in Theorem 2.1, we present the following example, which shows that Theorem 2.1 is a proper generalization of Theorem 1.2.

Example 2.1 Consider the space $X=\mathbb{R}$ with Euclidean metric. Take the sets

$$
A=(-\infty,-1] \text { and } B=[1,+\infty) \text {. }
$$

Obviously, $d(A, B)=2$. Let $T: A \rightarrow B$ be defined by $T x=-x$. Notice that $A_{0}=\{-1\}, B_{0}=\{1\}$ and $T\left(A_{0}\right) \subseteq B_{0}$. Also, it is clear that the pair $(A, B)$ has the weak $P$-property.

Consider

$$
\beta(t)= \begin{cases}\frac{1}{1+t}, & \text { if } 0 \leq t<1 \\ \frac{t}{1+t}, & \text { if } t \geq 1\end{cases}
$$


and $\psi(t)=\alpha t$ (with $\alpha \geq \frac{1}{2}$ ) for all $t \geq 0$. Note that $\beta \in S$ and $\psi \in \Psi$. For all $x, y \in A$, we have

$$
d(T x, T y)=|x-y| \quad \text { and } \quad M(x, y)=\max \{|x-y|,-2 x,-2 y\} .
$$

We shall show that $T$ is a generalized almost $\psi$-Geraghty contraction. Without loss of generality, consider the case where $x \geq y$. Then we have $M(x, y)=-2 y$ and $d(T x, T y)=x-y$.

In this case, we see that

$$
\begin{aligned}
\psi(d(T x, T y)) & =\alpha(x-y) \leq \alpha(-x-y-2) \\
& \leq 2 \alpha^{2}(-x-y-2) \leq[-2 \alpha y][\alpha(-x-y-2)] \\
& =[-2 \alpha y][\alpha(-2 y-2)-\alpha(x-y)] \\
& =\psi(M(x, y))[\psi(M(x, y)-d(A, B))-\psi(d(T x, T y))] .
\end{aligned}
$$

Therefore

$$
\psi(d(T x, T y)) \leq \frac{\psi(M(x, y))}{1+\psi(M(x, y))} \psi(M(x, y)-d(A, B)) .
$$

On the other hand, we know that $\psi(M(x, y))=-2 \alpha y \geq 1$ for all $x, y \in A$ with $x \geq y$. Hence,

$$
\beta(\psi(M(x, y)))=\frac{\psi(M(x, y))}{1+\psi(M(x, y))},
$$

and from (37) we deduce

$$
\psi(d(T x, T y)) \leq \beta(\psi(M(x, y))) \psi(M(x, y)-d(A, B)) .
$$

Thus, all hypotheses of Theorem 2.1 are satisfied, and $x^{*}=-1$ is the unique best proximity point of the map $T$.

On the other hand, $T$ is not a Geraghty contraction. Indeed, taking $x=-1$ and $y=-2$, we get

$$
d(T x, T y)=1>\frac{1}{2}=\beta(d(x, y)) d(x, y) .
$$

Then Theorem 1.2 (the main result of Caballero et al. [6]) is not applicable.

Similarly, we cannot apply Theorem 1.3 because $T$ is not a $\psi$-Geraghty contraction. Let $x=-1, y=-2$ and $\psi(t)=\alpha t$ with $\alpha<2$. Then $T$ does not satisfy (8).

If in Theorem 2.1 we take $\psi(t)=t$ for all $t \geq 0$, then we deduce the following corollary.

Corollary 2.1 Let $(A, B)$ be a pair of nonempty closed subsets of a complete metric space $(X, d)$ such that $A_{0}$ is nonempty. Let $T: A \rightarrow B$ be a non-self-mapping satisfying $T\left(A_{0}\right) \subseteq B_{0}$ and

$$
d(T x, T y) \leq \beta(M(x, y))[M(x, y)-d(A, B)]+L[N(x, y)-d(A, B)]
$$


for all $x, y \in A$ where $\beta \in S, L \geq 0$,

$$
\begin{aligned}
& M(x, y)=\max \{d(x, y), d(x, T x), d(y, T y)\}, \\
& N(x, y)=\min \{d(x, T x), d(y, T y), d(x, T y), d(y, T x)\} .
\end{aligned}
$$

Assume that the pair $(A, B)$ has the weak P-property. Then $T$ has a unique best proximity point in $A$.

If further in the above corollary we take $\beta(t)=r$ where $0 \leq r<1$, then we deduce another particular result.

Corollary 2.2 Let $(A, B)$ be a pair of nonempty closed subsets of a complete metric space $(X, d)$ such that $A_{0}$ is nonempty. Let $T: A \rightarrow B$ be a non-self-mapping satisfying $T\left(A_{0}\right) \subseteq B_{0}$ and

$$
d(T x, T y) \leq r[M(x, y)-d(A, B)]+L[N(x, y)-d(A, B)]
$$

for all $x, y \in A$ where $0 \leq r<1, L \geq 0$,

$$
\begin{aligned}
& M(x, y)=\max \{d(x, y), d(x, T x), d(y, T y)\}, \\
& N(x, y)=\min \{d(x, T x), d(y, T y), d(x, T y), d(y, T x)\} .
\end{aligned}
$$

Assume that the pair $(A, B)$ has the weak P-property. Then $T$ has a unique best proximity point in A.

\section{Application to fixed point theory}

The case $A=B$ in Theorem 2.1 corresponds to a self-mapping and results in an existence and uniqueness theorem for a fixed point of the map $T$. We state this case in the next theorem.

Theorem 3.1 Let $(X, d)$ be a complete metric space. Suppose that $A$ is a nonempty closed subset of X. Let $T: A \rightarrow A$ be a mapping such that

$$
\psi(d(T x, T y)) \leq \beta(\psi(M(x, y))) \psi(M(x, y))+L \psi(N(x, y)) \quad \text { for any } x, y \in A,
$$

where $\psi \in \Psi, \beta \in S, L \geq 0$,

$$
\begin{aligned}
& M(x, y)=\max \{d(x, y), d(x, T x), d(y, T y)\} \quad \text { and } \\
& N(x, y)=\min \{d(x, T x), d(y, T y), d(x, T y), d(y, T x)\} .
\end{aligned}
$$

Then T has a unique fixed point.

Finally, taking $\psi(t)=t$ in Theorem 3.1, we get another fixed point result. 
Corollary 3.1 Let $(X, d)$ be a complete metric space. Suppose that $A$ is a nonempty closed subset of $X$. Let $T: A \rightarrow A$ be a mapping such that

$$
d(T x, T y) \leq \beta(M(x, y)) M(x, y)+L N(x, y) \quad \text { for any } x, y \in A,
$$

where $\beta \in S, L \geq 0$,

$$
\begin{aligned}
& M(x, y)=\max \{d(x, y), d(x, T x), d(y, T y)\} \quad \text { and } \\
& N(x, y)=\min \{d(x, T x), d(y, T y), d(x, T y), d(y, T x)\} .
\end{aligned}
$$

Then T has a unique fixed point.

Remark 3.1 The best proximity theorem given in this work, more precisely Theorem 2.1, is a quite general result. It is a generalization of Theorem 2.1 in [14], Theorem 8 in [5], and also Theorem 1.2 given in Section 1. In addition, Corollary 3.1 improves Theorem 1.1.

Remark 3.2 Very recently, Karapınar and Samet [15] proved that the function $d_{\varphi}=\varphi \circ d$ on the set $X$, where $\varphi \in \Psi$ is also a metric on $X$. Therefore, some of the fixed theorems regarding contraction mappings defined via auxiliary functions from the set $\Psi$ can be in fact deduced from the existing ones in the literature. However, our main result given in Theorem 2.1 is not a consequence of any existing theorems due to the fact that the contraction condition contains the term $d(A, B)$.

On the other hand, the definition of $d_{\varphi}=\varphi \circ d$ can be used to show that Theorem 3.1 follows from Corollary 3.1. Nevertheless, Corollary 3.1 and hence Theorem 3.1 are still new results.

\section{Competing interests}

The authors declare that they have no competing interests.

\section{Authors' contributions}

All authors contributed equally and significantly in writing this article. All authors read and approved the manuscript.

\section{Author details}

1 Department of Mathematics, Jubail College of Education, Dammam University, P.O. Box 12020, Industrial Jubail, 31961, Saudi Arabia. ${ }^{2}$ Department of Mathematics, Atilim University, Incek, Ankara 06836, Turkey. ${ }^{3}$ Nonlinear Analysis and Applied Mathematics Research Group (NAAM), King Abdulaziz University, Jeddah, Saudi Arabia. ${ }^{4}$ Young Researchers and Elite Club, Rasht Branch, Islamic Azad University, Rasht, Iran.

\section{Acknowledgements}

The authors thank to the referees for their careful reading and valuable comments and remarks which contributed to the improvement of the article.

Received: 11 November 2013 Accepted: 24 January 2014 Published: 11 Feb 2014

References

1. Banach, S: Sur les opérations dans les ensembles abstraits et leur application aux équations intégrales. Fundam. Math. 3, 133-181 (1922)

2. Al-Thagafi, MA, Shahzad, N: Convergence and existence results for best proximity points. Nonlinear Anal. 70, 3665-3671 (2009)

3. Anuradha, J, Veeramani, P: Proximal pointwise contraction. Topol. Appl. 156, 2942-2948 (2009)

4. Basha, SS, Veeramani, P: Best proximity pair theorems for multifunctions with open fibres. J. Approx. Theory 103, 119-129 (2000)

5. Bilgili, N, Karapınar, E, Sadarangani, K: A generalization for the best proximity point of Geraghty-contractions. J. Inequal. Appl. (2013). doi:10.1186/1029-242X-2013-286

6. Caballero, J, Harjani, J, Sadarangani, K: A best proximity point theorem for Geraghty-contractions. Fixed Point Theory Appl. (2012). doi:10.1186/1687-1812-2012-231 
7. Jleli, M, Samet, B: Best proximity points for $\alpha$ - $\psi$-proximal contractive type mappings and applications. Bull. Sci. Math. 137, 977-995 (2013). doi:10.1016/j.bulsci.2013.02.003

8. Eldred, AA, Veeramani, P: Existence and convergence of best proximity points. J. Math. Anal. Appl. 323, 1001-1006 (2006)

9. De la Sen, M: Fixed point and best proximity theorems under two classes of integral-type contractive conditions in uniform metric spaces. Fixed Point Theory Appl. (2010). doi:10.1155/2010/510974

10. Karapınar, E: Best proximity points of cyclic mappings. Appl. Math. Lett. 25, 1761-1766 (2012)

11. Karapınar, E: On best proximity point of $\psi$-Geraghty contractions. Preprint

12. Karapınar, E, Erhan, IM: Best proximity point on different type contractions. Appl. Math. Inform. Sci. 3, $342-353$ (2011)

13. Karapınar, E: Best proximity points of Kannan type cylic weak $\phi$-contractions in ordered metric spaces. An. Univ. "Ovidius" Constanţa, Ser. Mat. 20, 51-64 (2012)

14. Karapınar, E: On best proximity point of $\psi$-Geraghty contractions. Fixed Point Theory Appl. (2013). doi:10.1186/1687-1812-2013-200

15. Karapınar, E, Samet, B: A note on ' $\psi$-Geraghty type contractions.' Fixed Point Theory Appl. (2014). doi:10.1186/1687-1812-2014-26

16. Karapınar, E, Pragadeeswarar, V, Marudai, M: Best proximity point for generalized proximal weak contractions in complete metric space. J. Appl. Math. 2013, Article ID 150941 (2013)

17. Kirk, WA, Reich, S, Veeramani, P: Proximinal retracts and best proximity pair theorems. Numer. Funct. Anal. Optim. 24 851-862 (2003)

18. Kumam, P, Aydi, H, Karapınar, E, Sintunavarat, W: Best proximity points and extension of Mizoguchi-Takahashi's fixed point theorem. Fixed Point Theory Appl. (2013). doi:10.1186/1687-1812-2013-242

19. Markin, J, Shahzad, N: Best approximation theorems for nonexpansive and condensing mappings in hyperconvex spaces. Nonlinear Anal. 70, 2435-2441 (2009)

20. Mongholkeha, C, Cho, YJ, Kumam, P: Best proximity points for Geraghty's proximal contraction mappings. Fixed Point Theory Appl. (2013). doi:10.1186/1687-1812-2013-180

21. Mongholkeha, C, Cho, YJ, Kumam, P: Best proximity points for generalized proximal C-contraction mappings in metric spaces with partial orders. J. Inequal. Appl. (2013). doi:10.1186/1029-242X-2013-94

22. Mongholkeha, C, Kumam, P: Best proximity points for asymptotic proximal pointwise weaker Meir-Keeler type $\psi$-contraction mappings. J. Egypt. Math. Soc. 21(2), 87-90 (2013)

23. Mongholkeha, C, Kumam, P: Some common best proximity points for proximity commuting mappings. Optim. Lett. 7(8), 1825-1836 (2013)

24. Mongholkeha, C, Kumam, P: Best proximity point theorems for generalized cyclic contractions in ordered metric spaces. J. Optim. Theory Appl. 155, 215-226 (2012)

25. Nashine, HK, Vetro, C, Kumam, P: Best proximity point theorems for rationasl proximal contractions, for proximity commuting mappings. Fixed Point Theory Appl. (2013). doi:10.1186/1687-1812-2013-95

26. Pragadeeswarar, V, Marudai, M: Best proximity points: approximation and optimization in partially ordered metric spaces. Optim. Lett. (2012). doi:10.1007/s11590-012-0529-x

27. Raj, VS, Veeramani, P: Best proximity pair theorems for relatively nonexpansive mappings. Appl. Gen. Topol. 10, 21-28 (2009)

28. Raj, VS: A best proximity theorem for weakly contractive non-self mappings. Nonlinear Anal. 74, 4804-4808 (2011)

29. Raj, VS: Banach's contraction principle for non-self mappings. Preprint

30. Samet, B: Some results on best proximity points. J. Optim. Theory Appl. (2013). doi:10.1007/s10957-013-0269-9

31. Shahzad, N, Basha, SS, Jeyaraj, R: Common best proximity points: global optimal solutions. J. Optim. Theory Appl. 148, 69-78 (2011)

32. Srinivasan, PS: Best proximity pair theorems. Acta Sci. Math. 67, 421-429 (2001)

33. Geraghty, M: On contractive mappings. Proc. Am. Math. Soc. 40, 604-608 (1973)

34. Zhang, J, Su, Y, Cheng, Q: A note on 'A best proximity point theorem for Geraghty-contractions.' Fixed Point Theory Appl. (2013). doi:10.1186/1687-1812-2013-99

10.1186/1687-1812-2014-32

Cite this article as: Aydi et al.: Best proximity points of generalized almost $\psi$-Geraghty contractive

non-self-mappings. Fixed Point Theory and Applications 2014, 2014:32

\section{Submit your manuscript to a SpringerOpen ${ }^{\circ}$ journal and benefit from:}

- Convenient online submission

- Rigorous peer review

- Immediate publication on acceptance

- Open access: articles freely available online

- High visibility within the field

- Retaining the copyright to your article

Submit your next manuscript at $>$ springeropen.com 